\title{
Effect of Implant Location on Palateless Complete Overdenture Retention: an In Vitro Study
}

\author{
Nesma El-Amier ${ }^{1}$, Ehab Elsaih ${ }^{1}$, Mona Gibreel ${ }^{1,2}$, Hassan El-Motaiam ${ }^{1}$ \\ ${ }^{1}$ Department of Prosthodontics, Faculty of Dentistry, Mansoura University, Mansoura, Egypt. \\ ${ }^{2}$ Department of Biomaterials Science and Turku Clinical Biomaterials Centre-TCBC, Institute of Dentistry, University of \\ Turku, Turku, Finland.
}

\author{
Corresponding Author: \\ Nesma El-Amier \\ Department of Prosthodontics, Faculty of Dentistry \\ Mansoura University \\ 68 El-Gomhoreya Street, P.O. 35516, Mansoura \\ Egypt \\ Phone: +201003700618; +971567126787 \\ E-mail: nesma_el_amier@mans.edu.eg
}

\begin{abstract}
Objectives: The purpose of this in vitro study was to evaluate effect of implant location on initial retention values of palateless complete overdentures retained by four o-rings at different inter-implant distances.

Material and Methods: Two standard acrylic models representing completely edentulous maxillary arches were used. Four single piece ball type implants were placed in each model. Models were divided into two groups according to the distance between anterior and posterior implants. Two canine implants with $32 \mathrm{~mm}$ inter-implant distance were placed in both models. In one model (G1), two posterior implants were placed in second premolar region away from canine implants by $14 \mathrm{~mm}$ on both sides, while in the other model $(\mathrm{G} 2)$, the two posterior implants were placed in first molar region away from canine implants by $22 \mathrm{~mm}$ on both sides. Eighteen palateless complete overdentures were constructed for each model. Overdentures were retained by four o-rings. Initial axial (central), and para-axial (anterior, posterior, and lateral) retention values of overdentures were estimated and compared using a universal testing machine.

Results: Independent t-test revealed that implant location has a significant role in palateless complete overdenture retention with a level of significance set at $\mathrm{P}<0.05$.

Conclusions: For in vitro simulated palateless implant overdentures retained by four o-rings, increasing the inter-implant distance between anterior and posterior implants is favourable for a more retentive prosthesis.
\end{abstract}

Keywords: dental implants; dental prosthesis design; implant-supported denture; maxilla; palate; retention.

\author{
Accepted for publication: 24 September 2018 \\ To cite this article: \\ El-Amier N, Elsaih E, Gibreel M, El-Motaiam H. \\ Effect of Implant Location on Palateless Complete Overdenture Retention: an In Vitro Study \\ J Oral Maxillofac Res 2018;9(3):e3 \\ URL: http://www.ejomr.org/JOMR/archives/2018/3/e3/v9n3e3.pdf \\ doi: $10.5037 /$ jomr.2018.9303
}




\section{INTRODUCTION}

Variable designs of maxillary implant overdentures are available in clinical practice [1-3]. The patient needs and desires may require the natural palate of the patient to be uncovered while wearing the maxillary denture to optimize their oral sensation and comfort $[\underline{4}, \underline{5}]$. These patients include gaggers, patients with large maxillary tori or bony exostoses, singers and actors due to voice changes caused by any change in the prosthesis volume, food and wine consumers who use their palates to taste subtle differences in preparations, and new denture wearers unfamiliar with the palatal aspect of the maxillary denture [ $[$ ] .

Omission of palatal aspect of maxillary denture adversely affects its retention, therefore maxillary implants were installed to sustain retention, support and stability $[1,4,6]$. Several studies have recommended a minimum of four implants to be placed in maxilla while removing partially the palatal coverage $[\underline{2}, \underline{3}, \underline{6-9}]$.

O-rings are commonly used attachments especially in anterior maxilla as they provide more occlusal and bucco-lingual space for artificial teeth, in addition to design simplicity, ease of use and maintenance, less costly than other attachment options, time effective, and they offer varying degrees of retention. Moreover, o-rings act as buffers so less transfer of stresses and loading moments to the implants $[\underline{5}, \underline{10-13}]$.

Canine area is a key implant position anteriorly $[5,14]$, while posterior key implant position is still controversial. First molar area was reported as a posterior key implant position since the bite force doubles in molar area when compared to premolar area [14]. Moreover, first molar area shows moderate resorption rates, while premolar area shows high resorption rates [15]. However, second premolar area may be preferred to avoid maxillary sinus and consequently the need for extensive grafting and sinus lift procedures $[\underline{5}, \underline{16}]$.

In the former in vivo test [17], measuring retention intraorally was complicated due to lack of reproducibility of dentures removal process as fixation of patient's head combined with denture removal is difficult to be controlled, in addition to lack of simplicity, patient intolerance and steps performed during measurements that may be source of an error. On contrary, in vitro tests were reported to be more accurate as they avoid oral environment interferences, and allow standardization of the tested conditions $[\underline{18}, \underline{19}]$.

The potential influence of implant location on overdenture retention was widely investigated for mandibular overdentures and seldom investigated for maxillary overdentures [20-25]. Since, retention has a direct relationship with patient satisfaction [26]; the aim of this study was to evaluate effect of implant location on initial retention values of palateless complete overdentures retained by four o-rings at different inter-implant distances using a standardized in vitro test. The research hypothesis was that interimplant distance significantly affects prosthesis retention.

\section{MATERIAL AND METHODS \\ Construction and grouping of the study models}

This in vitro study was conducted over two transparent acrylic models of the same geometry reproducing completely edentulous, moderately developed, square shaped maxillary arches with no undercuts and with moderate depth palatal vaults. Models were divided into two groups according to the results of a previous pilot study for implant site determination [17]. Both models received four ball type single piece implants (SlimLine, Dentium Co. Ltd., Suwon, South Korea) of $3.5 \mathrm{~mm}$ diameter and a length of $12 \mathrm{~mm}$ anteriorly and $10 \mathrm{~mm}$ posteriorly. Two canine implants were placed in both models with an inter-implant distance of $32 \mathrm{~mm}$. In one model (G1), two posterior implants were placed in second premolar area away from canine implants by $14 \mathrm{~mm}$ on both sides, while in the second model (G2), the two posterior implants were placed in first molar area away from canine implants by $22 \mathrm{~mm}$ on both sides.

The mucosal surface of the models was covered with $3 \mathrm{~mm}$ thickness silicone based soft liner (Promedica, Neumünster-Gartenstadt, Germany) to simulate resilient edentulous ridge mucosa [27] with marks at pre-determined implant sites as follows. Three $\mathrm{mm}$ thickness base plate wax was adapted over mucosal surface of the models, then tissue punch $(3 \mathrm{~mm}$ diameter, SlimLine, Dentium Co. Ltd., Suwon, South Korea) was used to make four wax free marks at target implant sites, after then models were boxed and poured into dental stone. Stone index was developed for each model with four stoppers to guarantee accurate repositioning of the index over its model after wax elimination, as well as evenness of artificial mucosal thickness. After wax elimination, fitting surface of stone indices was painted with sodium alginate separating medium (Acrostone, Acrostone Dental factory, under exclusive license of England, Egypt), and then packed with silicone based soft liner. Each stone index was firmly held against its model till complete 
polymerization. Stone indices were then separated, excess silicon was trimmed, and glazing was applied (Figure 1).

\section{Implant installation in the models}

The straight hand piece of a micro-motor was mounted on a dental surveyor (Surveyor Milling Machine, Marathon-103, Saeyang Microtech Co., South Korea) to drill four channels at target implant sites perpendicular to the horizontal plane and parallel to each other. The successive drills of
Slim Line implant surgical kit (Dentium Co. Ltd., Suwon, South Korea) were used to widen implant houses with a final drill of $3.4 \mathrm{~mm}$ diameter. Parallelism of drilled implant houses was verified using parallel pins (Dentium Co. Ltd., Suwon, South Korea) as well as the analysing rod of the dental surveyor. Implants were screwed into their parallel prepared channels using ratchet wrench till implant plateau is in level with the crest of the acrylic ridge, while implant trans-mucosal portion is completely included within the silicone layer of the model (Figure 2).

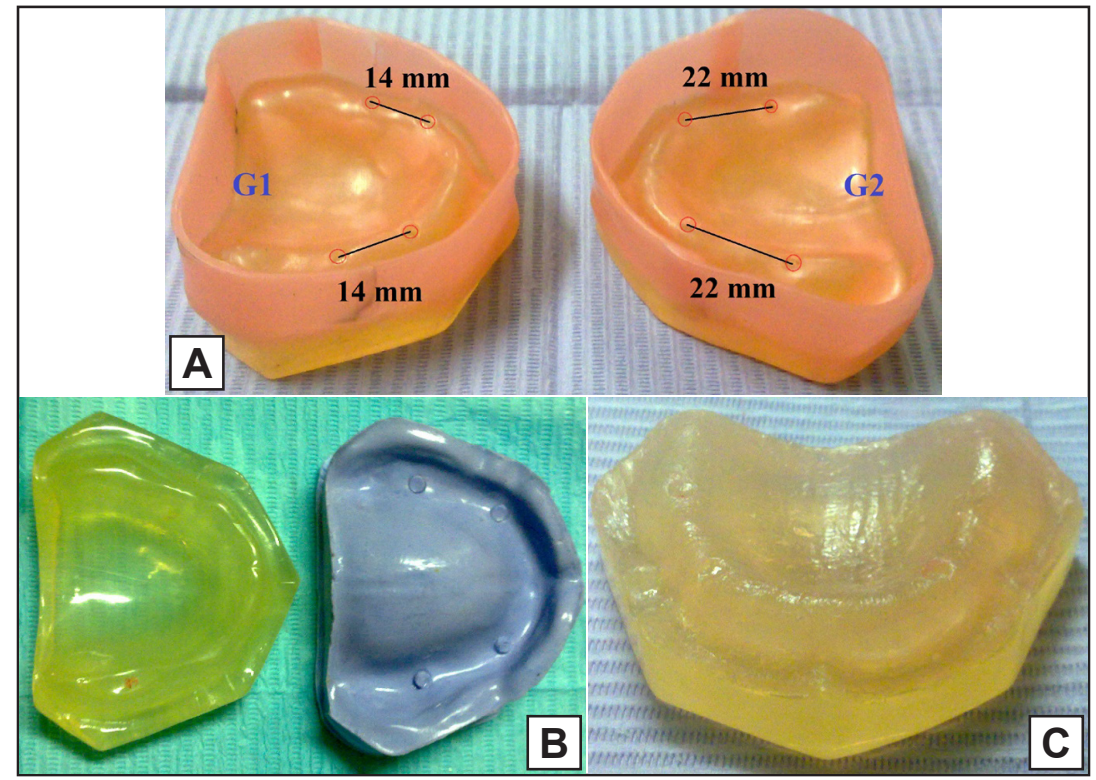

Figure 1. $A=$ maxillary acrylic models waxed and boxed with $3 \mathrm{~mm}$ wax free circles at predetermined implant sites $\mathrm{B}=$ transparent acrylic model (left) and stone index with four stoppers (right) after separation and wax elimination. $\mathrm{C}=$ the acrylic model covered with even thickness silicone layer representing oral mucosa.

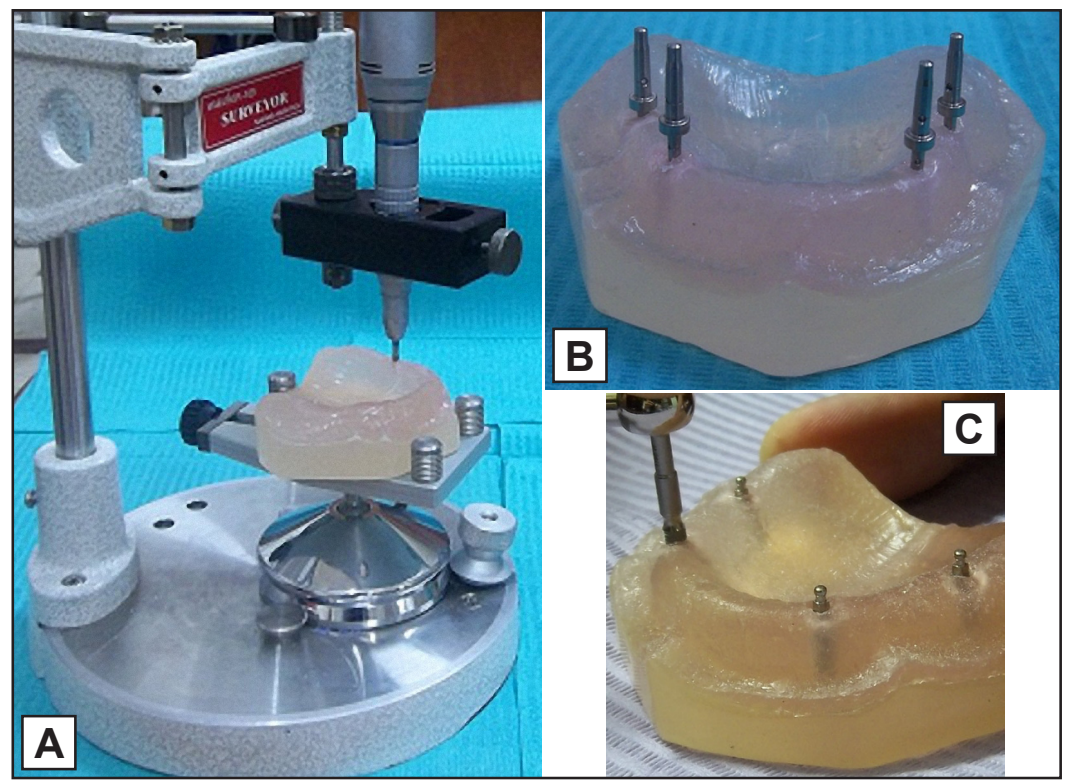

Figure 2. $\mathrm{A}=$ straight hand piece mounted on dental surveyor to drill four parallel implant houses. $\mathrm{B}=$ parallel pins to verify parallelism of drilled implant houses.

$\mathrm{C}=$ four ball type single piece implants were screwed into their parallel drilled channels using ratchet wrench. 


\section{Construction of palateless complete overdentures}

Eighteen palateless complete overdentures were constructed for each model. Sample size $(\mathrm{n}=18)$ was calculated using statistical power analysis $\left(\mathrm{G}^{*}\right.$ Power version 3.1.9, Heinrich-Heine-Universität Düsseldorf, Düsseldorf, Germany) to achieve a power of $99.9 \%$ with a two tailed, significance level (alpha) set at 0.05 . Calculations were made based on the results of a previous study [17] which demonstrated that inter-implant distance has a significant effect on palateless implant overdentures retained by four o-rings $(\mathrm{P}=0.001)$.

Socket spacers (Dentium Co. Ltd., Suwon, South Korea) were fitted over implant ball abutments before duplicating the models into type III dental stone (Protechno, Vilamalla Girona, Spain). Palateless dentures were constructed according to Farmer and Connelly guidelines [28]. Metal frameworks of palateless dentures were verified over models for proper adaptation. Four U-shaped wire loops were attached to the waxed up dentures palatal to canines and second molars on both sides in agreement with Rutkunas et al. [29] who considered canines and second molars as reliable points for measuring denture axial and para-axial retentions. Dentures were processed in heat cured acrylic resin (Acrostone, Acrostone Dental factory, under exclusive license of England, Egypt). Polished dentures were fitted over silicone lined models to verify complete seating and intimate contact (Figure 3).

Female housings (Slim One Body Ball Socket with O-ring [BPF3], Dentium Co. Ltd., Suwon, South Korea) were assembled over ball heads. Vents were drilled in denture depressions created by socket spacers opposite to ball heads to release excess pick up material. The female housings were picked up to palateless dentures using auto-polymerizing acrylic resin (Acrostone; Acrostone Dental factory, under exclusive license of England, Egypt) while dentures were seated against their models under firm finger pressure. After complete setting, excess resin was removed and the fully prepared set was kept in a water bath of $37{ }^{\circ} \mathrm{C}$ distilled water to simulate humidity of the oral cavity and to prevent warpage of the processed overdentures.

\section{Evaluation of prosthesis retention}

The wire loops placed palatal to canines and second molars on both sides of the overdentures were connected by centrally looped anterior, posterior, lateral and diagonal wires $\left(\right.$ Remanium $^{\circledR}$, diameter 0.5 $\mathrm{mm}$, Dentaurum, Pforzheim, Germany) the same as in a former study [17]. Universal testing machine (LRXPlus, Lloyd Instruments Ltd., West Sussex, UK) with a load cell of $5 \mathrm{kN}$ was used to estimate retention by recording the maximum dislodging force at a crosshead speed of $50 \mathrm{~mm} / \mathrm{min}$.

Maximum dislodging force was recorded at the moment of complete detachment of the overdenture away from the underlying model. The tested model was stabilized against the stainless steel plate of the testing machine by long threaded locking screws. Artificial saliva made of $60 \%$ glycerin solution was dropped over model's silicon mucosa, and then the overdenture was joined to the model under a force of $10 \mathrm{~kg}(98 \mathrm{~N})$ applied for 20 seconds to evenly disperse the solution across the artificial mucosa. A coupling hook was fixed to the upper part of the universal testing machine to be attached to withdrawal loops of anterior, posterior, and lateral wires to measure overdenture anterior, posterior, and lateral retentions respectively, then it was attached to withdrawal loop at the crossing point of the two diagonal wires to measure overdenture central (axial) retention (Figure 4). Each loop was subjected to five consecutive pulls with three minutes intervals for recovery, and the mean value of the five readings was calculated for each site. Maximum dislodging force was recorded in grams using a computer program (Nexygen ${ }^{\mathrm{TM}} \mathrm{MT}$, Lloyd Instruments Ltd., West Sussex, UK).

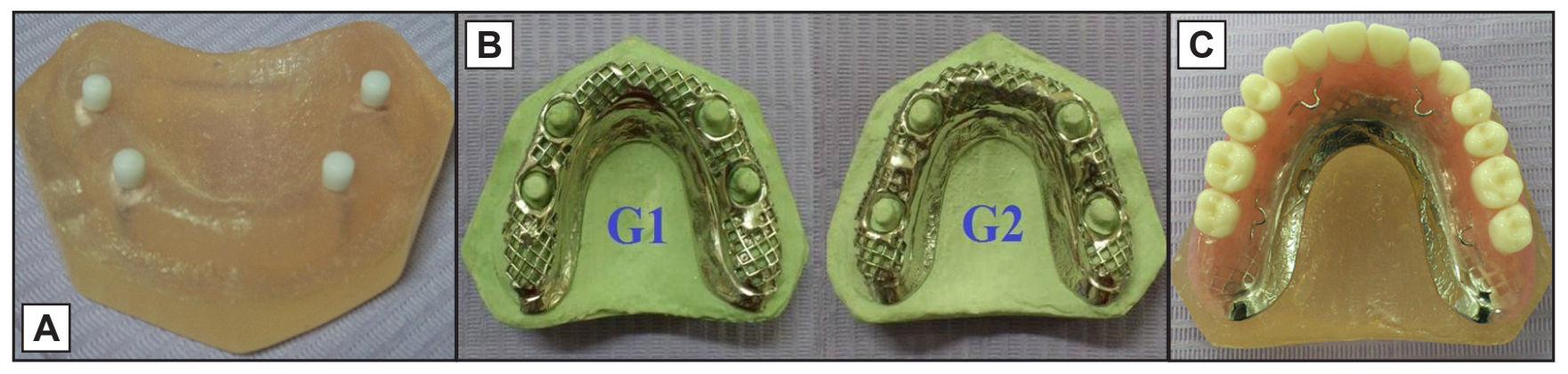

Figure 3. $\mathrm{A}=$ socket spacers over ball abutments. $\mathrm{B}=$ palateless metal frameworks over stone casts. $\mathrm{C}=$ finished palateless overdenture with loops attached. 


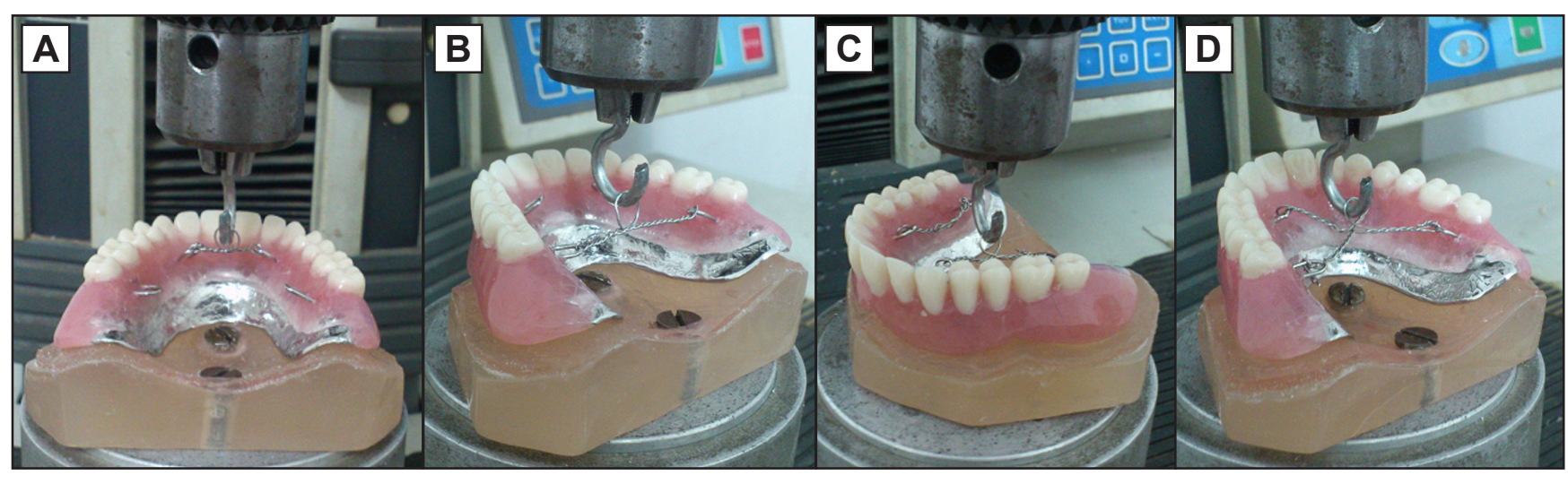

Figure 4. While measuring retention with universal testing machine.

$\mathrm{A}=$ anterior retention; $\mathrm{B}=$ posterior retention; $\mathrm{C}=$ lateral retention; $\mathrm{D}=$ central retention.

\section{Statistical analysis}

Collected data was statistically analyzed using Statistical Package for Social Science (IBM SPSS Statistics version 17, IBM Corp., Armonk, New York, USA). Data was found parametric by KolmogorovSmirnov test $(\mathrm{P}>0.05)$. Data were expressed as mean and standard deviation (M [SD]). Comparisons of the two different groups were performed by independent t-test. Significance was considered when P-value was less than 0.05 .

Table 1. Comparisons for in vitro mean retention values of G1 versus $\mathrm{G} 2$ measured in grams

\begin{tabular}{l|c|c|c|c}
\hline \multirow{2}{*}{ Site } & G1 $(\mathbf{n}=\mathbf{1 8})$ & $\mathbf{G 2}(\mathbf{n}=\mathbf{1 8})$ & \multirow{2}{*}{$\begin{array}{c}\text { t-test } \\
\text { df }=\mathbf{3 4}\end{array}$} & \multirow{2}{*}{ P-value $^{\mathbf{a}}$} \\
\cline { 2 - 3 } & Mean (SD) & Mean (SD) & \\
\hline Anterior & $1031.9(19.9)$ & $841.3(10.6)$ & 35.8 & 0.001 \\
\hline Posterior & $921.8(12.7)$ & $1208.1(26)$ & 41.9 & 0.001 \\
\hline Lateral & $824.4(8.9)$ & $922.1(35.3)$ & 11.4 & 0.001 \\
\hline Central & $106.7(41.6)$ & $1344.6(46.2)$ & 19.4 & 0.001 \\
\hline
\end{tabular}

${ }^{\text {aP }}$ statistically significant at level $\mathrm{P}<0.05$. Comparisons with independent t-test.

$\mathrm{SD}=$ standard deviation; $\mathrm{df}=$ degree of freedom .

Table 2. Comparisons for G1 mean retention values of in vivo test versus in vitro test measured in grams

\begin{tabular}{l|c|c|c|c}
\hline \multirow{2}{*}{ Site } & $\begin{array}{c}\text { G1 in vivo } \\
(\mathbf{n}=\mathbf{1 8})\end{array}$ & $\begin{array}{c}\text { G1 in vitro } \\
(\mathbf{n}=\mathbf{1 8})\end{array}$ & \multirow{2}{*}{$\begin{array}{c}\text { t-test } \\
\mathbf{d f}=\mathbf{3 4}\end{array}$} & \multirow{2}{*}{ P-value $^{\mathrm{a}}$} \\
\cline { 2 - 4 } & Mean (SD) & Mean (SD) & & \\
\hline Anterior & $206.2(217.3)$ & $1031.9(19.9)$ & 19.9 & 0.001 \\
\hline Posterior & $1385.9(18.2)$ & $921.8(12.7)$ & 88.8 & 0.001 \\
\hline Lateral & $1423.4(111.2)$ & $824.4(8.9)$ & 22.8 & 0.001 \\
\hline Central & $1800.3(175.3)$ & $1060.7(41.6)$ & 17.4 & 0.001 \\
\hline
\end{tabular}

${ }^{\text {ap }}$ statistically significant at level $\mathrm{P}<0.05$. Comparisons with independent t-test.

$\mathrm{SD}=$ standard deviation; $\mathrm{df}=$ degree of freedom .

\section{RESULTS}

The mean retentive forces of maxillary implant overdentures estimated in this study ranged from 824.4 to $1344.6 \mathrm{~g}(8.1$ to $13.2 \mathrm{~N})$. The independent t-test revealed that implant location had a significant role in palateless complete overdenture retention at $\mathrm{P}<0.05$. Table 1 shows the in vitro mean retention values of G1 versus G2 at different measurement sites (anterior, posterior, lateral and central). Anterior mean retention values were significantly higher in G1 $(\mathrm{P}=0.001)$, while posterior, lateral, and central mean retention values were significantly higher in $\mathrm{G} 2(\mathrm{P}=$ 0.001 ). The mean retention values of the previous in vivo test [17] were compared with those of current in vitro test in Tables 2 and 3. Table 2 compares between in vivo and in vitro mean retention values for $\mathrm{G} 1$ at different measurement sites (anterior, posterior, lateral and central). The axial (central) and para-axial (anterior, posterior, and lateral) mean retention values of the in vivo test were significantly higher than those of the in vitro test $(\mathrm{P}=0.001)$. Table 3 compares between in vivo and in vitro mean retention values for G2 at different measurement sites (anterior, posterior,

Table 3. Comparisons for G2 mean retention values of in vivo test versus in vitro test measured in grams

\begin{tabular}{l|c|c|c|c}
\hline \multirow{2}{*}{ Site } & $\begin{array}{c}\text { G2 in vivo } \\
(\mathbf{n}=\mathbf{1 8})\end{array}$ & $\begin{array}{c}\text { G2 in vitro } \\
(\mathbf{n}=\mathbf{1 8})\end{array}$ & $\begin{array}{c}\text { t-test } \\
\mathbf{d f}=\mathbf{3 4}\end{array}$ & \multirow{2}{*}{ P-value $^{\mathrm{a}}$} \\
\cline { 2 - 5 } & Mean (SD) & Mean (SD) & & \\
\hline Anterior & $1605.7(122.3)$ & $841.3(10.6)$ & 26.4 & 0.001 \\
\hline Posterior & $194.2(436.2)$ & $1208.1(26)$ & 7.1 & 0.001 \\
\hline Lateral & $1719.4(143.1)$ & $922.1(35.3)$ & 22.9 & 0.001 \\
\hline Central & $2074.1(131.9)$ & $1344.6(46.2)$ & 22.1 & 0.001 \\
\hline
\end{tabular}

${ }^{a} \mathrm{P}$ statistically significant at level $\mathrm{P}<0.05$. Comparisons with independent t-test.

$\mathrm{SD}=$ standard deviation; $\mathrm{df}=$ degree of freedom . 
lateral and central). G2 in vivo mean retention values were significantly higher than G2 in vitro mean retention values at all measurement sites (anterior, posterior, lateral and central $)(\mathrm{P}=0.001)$.

\section{DISCUSSION}

Since the configuration of the maxillary arch, height of the residual ridge, thickness of oral mucosa, and direction of the applied force are difficult to be standardized in the in vivo study; this in vitro test was performed to evaluate retention of palateless implant overdentures at different inter-implant distances when all variables are well controlled. This is in agreement with Alsabeeha et al. [19] who concluded that effective factors on retention must be investigated separately under well-controlled conditions to limit the influence of confounding variables on the outcome.

During function, removable prostheses resist dislodgements at different locations intraorally, therefore both axial (central) and para-axial rotational (anterior, posterior, and lateral) retentions were evaluated in this study. True unidirectional dislodging forces rarely occur in clinical scenarios, however a directional pull testing is considered an effective way of measuring retention and stability of the prosthesis during in vitro laboratory investigations $[\underline{25}, \underline{30}]$. The maximum dislodging force was recorded at a crosshead speed of $50 \mathrm{~mm} / \mathrm{min}$ as it approximates the speed of overdenture removal in vivo [30], in addition to that dislodgement speeds higher than $50 \mathrm{~mm} / \mathrm{min}$ result in lower measured value of maximum retentive force [29].

The mean retentive forces of maxillary implant overdentures estimated using this in vitro test ranged from 824.4 to $1344.6 \mathrm{~g}(8.1$ to $13.2 \mathrm{~N})$. This agreed with Ohya et al. [31] who reported a range for the mean retentive force of implant overdentures to be from 1.7 to $37 \mathrm{~N}$, and with Williams et al. [9] who recommended the retentive force of maxillary overdentures to be above $5 \mathrm{~N}$ to get a clinically acceptable degree of retention that is compatible with patient needs. Besimo and Guarneri [32] reported that retention strengths between 5 and $8 \mathrm{~N}$ may be sufficient for implant-retained overdentures during long-term function as well.

The results of this study supported the hypothesis that inter-implant distance can significantly affect prosthesis retention in agreement with many former research studies [20-25]. The significant difference in retention values between G1 and G2 reported in the prior in vivo test [17] was found and confirmed by the current in vitro test. However, the overall in vitro retention values were significantly lower than those measured in vivo. This may be attributed to less physical means of retention in the in vitro test as silicon based soft liner and artificial glycerin solution mimic but not exactly the same as natural oral mucosa and patient's natural saliva. Consequently, decreased adhesion, cohesion, interfacial surface tension, and peripheral seal which are important factors for prosthesis retention.

This is consistent with several studies $[\underline{18}, \underline{29}, \underline{33}, \underline{34}]$ which reported that oral environment presents a set of conditions that are difficult to simulate like humidity, presence of saliva, temperature variation, and patient load. Lack of these factors affects in vitro results that have been derived under closely controlled laboratory conditions of less clinical relevance and bear less relationship to the intraoral environment.

For anterior rotational retention, G1 showed significantly greater mean retention values than G2. This may be attributed to placing the implants in G1 more closely to point of force application than in G2. This finding was in agreement with Rutkunas et al. [29] who found that most attachments showed greater anterior retention where dislodging forces were applied in proximity to canine implants and less posterior retention where forces were applied away from the anterior canine implants for two implantretained overdentures.

For posterior para-axial retention, G2 showed significantly greater mean retention values than that of G1. This may be attributed to the proximity of posterior implants in G2 to point of force application than in G1, in addition to the resultant second class lever where anterior canine implants act as fulcrum (F), second premolar and first molar implants are the resistance (R), and central loop of the posterior wire where dislodging forces were applied is the force (E). Since, the resistance arm of G2 was longer than that of G1, G2 overdentures have better resisted the posterior dislodging forces [35].

For lateral para-axial rotational retention, G2 with its greater inter-implant distance between anterior and posterior implants has shown significantly higher lateral retention than G1. That means the longer the distance between two O-rings at one side, the greater is the lateral retention on that side. Michelinakis et al. [20] reported that the retention of two ball/socket attachments was greater at $29 \mathrm{~mm}$ inter-implant distance than at 19 and $23 \mathrm{~mm}$ inter-implant distances. The study of Tabatabaian et al. [23] showed a significantly greater resistance to dislodging forces for ball-retained overdenture at $35 \mathrm{~mm}$ inter-implant distance than at 15 and $25 \mathrm{~mm}$ inter-implant distances. 
Moreover, Shayegh et al. [24] found that increasing the inter-implant distance between two un-splinted attachments from 19 to $23 \mathrm{~mm}$ and from 23 to $29 \mathrm{~mm}$ has significantly increased the initial retention.

Theoretically, central axial retention of the prosthesis would be directly proportional with its anterior, posterior, and lateral retentions. Since, G2 has shown significantly greater posterior and lateral retentions, it is reasonable that it has a greater central axial retention as well. This is consistent with Scherer et al. [22,25] who declared that dislodging forces of the overdenture prosthesis increased with widely spaced implants.

The results of this research may be attributed to the mechanical nature of o-ring attachments, design of the models and measuring techniques, so it is recommended to support this research with other studies using other attachments, modelling designs and/or measurement techniques.

\section{CONCLUSIONS}

Within the limitations of this study, it was concluded that for palateless maxillary implant overdentures retained by four o-ring attachments, favourable anterior-posterior spread of implants by increasing the inter-implant distance between anterior and posterior implants is recommended for a more retentive prosthesis.

\section{ACKNOWLEDGMENTS AND DISCLOSURE STATEMENTS}

The authors report no conflicts of interest related to this study.

\section{REFERENCES}

1. Närhi TO, Hevinga M, Voorsmit RA, Kalk W. Maxillary overdentures retained by splinted and unsplinted implants: a retrospective study. Int J Oral Maxillofac Implants. 2001 Mar-Apr;16(2):259-66. [Medline: 11324214]

2. Kiener P, Oettertli M, Mericske E, Mericske-Stern R. Effectiveness of maxillary overdentures supported by implants: maintenance and prosthetic complications. Int J Prosthodont. 2001 Mar-Apr;14(2):133-40. [Medline: 11843449]

3. Cavallaro JS Jr, Tarnow DP. Unsplinted implants retaining maxillary overdentures with partial palatal coverage: report of 5 consecutive cases. Int J Oral Maxillofac Implants. 2007 Sep-Oct;22(5):808-14. [Medline: 17974117]

4. Ochiai KT, Williams BH, Hojo S, Nishimura R, Caputo AA. Photoelastic analysis of the effect of palatal support on various implant-supported overdenture designs. J Prosthet Dent. 2004 May;91(5):421-7. [Medline: 15153848] [doi: 10.1016/j.prosdent.2004.02.017]

5. Misch CE. Partial and complete edentulous maxilla implant treatment plans: Fixed and overdenture prostheses. In: Misch CE, editor. Dental implant prosthetics. St. Louis: Mosby; 2005. p. 281-94.

6. Lewis S, Sharma A, Nishimura R. Treatment of edentulous maxillae with osseointegrated implants. J Prosthet Dent. 1992 Sep;68(3):503-8. [Medline: 1432770] [doi: 10.1016/0022-3913(92)90419-B]

7. Vogel RC. Implant overdentures: a new standard of care for edentulous patients current concepts and techniques. Compend Contin Educ Dent. 2008 Jun;29(5):270-6; quiz 277-8. [Medline: 18795644]

8. Mericske-Stern R. Treatment outcomes with implant-supported overdentures: clinical considerations. J Prosthet Dent. 1998 Jan;79(1):66-73. [Medline: 9474544] [doi: 10.1016/S0022-3913(98)70196-9]

9. Williams BH, Ochiai KT, Hojo S, Nishimura R, Caputo AA. Retention of maxillary implant overdenture bars of different designs. J Prosthet Dent. 2001 Dec;86(6):603-7. [Medline: 11753311] [doi: 10.1067/mpr.2001.120838]

10. Porter JA Jr, Petropoulos VC, Brunski JB. Comparison of load distribution for implant overdenture attachments. Int J Oral Maxillofac Implants. 2002 Sep-Oct;17(5):651-62. [Medline: 12381065]

11. Tseng CG, Jiang YS. Mechanics analysis for implant-soft tissue retained overdentures. Journal of the Chinese Institute of Engineers. 2004 May;27(3):405-15. [doi: 10.1080/02533839.2004.9670887]

12. Winkler S, Piermatti J, Rothman A, Siamos G. An overview of the O-ring implant overdenture attachment: clinical reports. J Oral Implantol. 2002;28(2):82-6. [Medline: 12498450] [doi: 10.1563/1548-1336(2002)0282.3.CO;2]

13. Kobayashi M, Srinivasan M, Ammann P, Perriard J, Ohkubo C, Müller F, Belser UC, Schimmel M. Effects of in vitro cyclic dislodging on retentive force and removal torque of three overdenture attachment systems. Clin Oral Implants Res. 2014 Apr;25(4):426-34. [Medline: 23566266] [doi: 10.1111/clr.12156]

14. Misch CE, Silc JT. A key implant position for a fixed prosthesis: the first molar rule. Oral Health. 2009 Aug. [URL: https://www.oralhealthgroup.com/features/a-key-implant-position-for-a-fixed-prosthesis-the-first-molar-rule/]

15. Malo P, Nobre M. The 'All-on-4' implant concept for edentulous jaws. Implant Tribune 2008;3(11):6-11. [URL: https://www.dental-tribune.com/clinical/the-all-on-4-implant-concept-for-edentulous-jaws/]

16. Widbom C, Söderfeldt B, Kronström M. A retrospective evaluation of treatments with implantsupported maxillary overdentures. Clin Implant Dent Relat Res. 2005;7(3):166-72. [Medline: 16219247] [doi: $10.1111 / \mathrm{j} .1708-8208.2005 . t b 00061 . x]$ 
17. El-Amier NM, Elsaih EA, El-Motaiam HA, Al-Shahat MA. Effect of implant location on palateless complete overdenture retention: preliminary study. J Dent Implant. 2015 Jan;5(1):6-11. [doi: 10.4103/0974-6781.154418]

18. Rodrigues RC, Faria AC, Macedo AP, Sartori IA, de Mattos Mda G, Ribeiro RF. An in vitro study of non-axial forces upon the retention of an O-ring attachment. Clin Oral Implants Res. 2009 Dec;20(12):1314-9. [Medline: 19681968] [doi: 10.1111/j.1600-0501.2009.01742.x]

19. Alsabeeha NH, Payne AG, Swain MV. Attachment systems for mandibular two-implant overdentures: a review of in vitro investigations on retention and wear features. Int J Prosthodont. 2009 Sep-Oct;22(5):429-40. [Medline: 20095190]

20. Michelinakis G, Barclay CW, Smith PW. The influence of interimplant distance and attachment type on the retention characteristics of mandibular overdentures on 2 implants: initial retention values. Int J Prosthodont. 2006 Sep-Oct;19(5):507-12. [Medline: 17323731]

21. Doukas D, Michelinakis G, Smith PW, Barclay CW. The influence of interimplant distance and attachment type on the retention characteristics of mandibular overdentures on 2 implants: 6-month fatigue retention values. Int J Prosthodont. 2008 Mar-Apr;21(2):152-4. [Medline: 18546771]

22. Scherer MD, McGlumphy EA, Seghi RR, Campagni WV. Comparison of retention and stability of implant-retained overdentures based upon implant number and distribution. Int J Oral Maxillofac Implants. 2013 Nov-Dec;28(6):1619-28. [Medline: 24278931] [doi: 10.11607/jomi.3067]

23. Tabatabaian F, Saboury A, Sobhani ZS, Petropoulos VC. The effect of inter-implant distance on retention and resistance to dislodging forces for mandibular implant-tissue-supported overdentures. J Dent (Tehran). 2014 Sep;11(5):506-15. [Medline: 25628676]

24. Shayegh SS, Hakimaneh SM, Baghani MT, Shidfar S, Kashi FK, Zamanian A, Arezoobakhsh A. Effect of Interimplant Distance and Cyclic Loading on the Retention of Overdenture Attachments. J Contemp Dent Pract. 2017 Nov 1;18(11):1078-1084. [Medline: 29109325] [doi: 10.5005/jp-journals-10024-2179]

25. Scherer MD, McGlumphy EA, Seghi RR, Campagni WV. Comparison of retention and stability of two implantretained overdentures based on implant location. J Prosthet Dent. 2014 Sep;112(3):515-21. [Medline: 24819528] [doi: 10.1016/j.prosdent.2014.03.003]

26. Rutkunas V, Mizutani H, Takahashi H, Iwasaki N. Wear simulation effects on overdenture stud attachments. Dent Mater J. 2011;30(6):845-53.. [Medline: 22123008] [doi: 10.4012/dmj.2011-057]

27. Tokuhisa M, Matsushita Y, Koyano K. In vitro study of a mandibular implant overdenture retained with ball, magnet, or bar attachments: comparison of load transfer and denture stability. Int J Prosthodont. 2003 Mar-Apr;16(2):128-34. [Medline: 12737242]

28. Farmer JB, Connelly ME. Palateless dentures: help for the gagging patient. J Prosthet Dent. 1984 Nov;52(5):691-4. [Medline: 6387094] [doi: 10.1016/0022-3913(84)90143-4]

29. Rutkunas V, Mizutani H, Takahashi H. Influence of attachment wear on retention of mandibular overdenture. J Oral Rehabil. 2007 Jan;34(1):41-51. [Medline: 17207077] [doi: 10.1111/j.1365-2842.2006.01640.x]

30. Sadig W. A comparative in vitro study on the retention and stability of implant-supported overdentures. Quintessence Int. 2009 Apr;40(4):313-9. [Medline: 19417876]

31. Ohya K, Kanazawa M, Minakuchi S. Retentive force of stress-breaking attachments on maxillary implant overdentures. J Prosthodont Res. 2009 Apr;53(2):78-82. [Medline: 19318077] [doi: 10.1016/j.jpor.2008.09.002]

32. Besimo CE, Guarneri A. In vitro retention force changes of prefabricated attachments for overdentures. J Oral Rehabil. 2003 Jul;30(7):671-8. [Medline: 12791150] [doi: 10.1046/j.1365-2842.2003.01140.x]

33. Leung T, Preiskel HW. Retention profiles of stud-type precision attachments. Int J Prosthodont. 1991 Mar-Apr;4(2):175-9. [Medline: 1781881]

34. van Kampen F, Cune M, van der Bilt A, Bosman F. Retention and postinsertion maintenance of bar-clip, ball and magnet attachments in mandibular implant overdenture treatment: an in vivo comparison after 3 months of function. Clin Oral Implants Res. 2003 Dec;14(6):720-6. [Medline: 15015948] [doi: 10.1046/j.0905-7161.2003.00961.x]

35. Carr AB, Brown DT. Biomechanics of removable partial dentures. In: Carr AB, Brown DT, editors. McCracken's removable partial prosthodontics, 13th edition. St. Louis: Mosby; 2015. p. 21-8.

\section{To cite this article:}

El-Amier N, Elsaih E, Gibreel M, El-Motaiam H.

Effect of Implant Location on Palateless Complete Overdenture Retention: an In Vitro Study

J Oral Maxillofac Res 2018;9(3):e3

URL: http://www.ejomr.org/JOMR/archives/2018/3/e3/v9n3e3.pdf

doi: $10.5037 /$ jomr.2018.9303 
Copyright (C) El-Amier N, Elsaih E, Gibreel M, El-Motaiam H. Published in the JOURNAL OF ORAL \& MAXILLOFACIAL RESEARCH (http://www.ejomr.org), 30 September 2018.

This is an open-access article, first published in the JOURNAL OF ORAL \& MAXILLOFACIAL RESEARCH, distributed under the terms of the Creative Commons Attribution-Noncommercial-No Derivative Works 3.0 Unported License, which permits unrestricted non-commercial use, distribution, and reproduction in any medium, provided the original work and is properly cited. The copyright, license information and link to the original publication on (http://www.ejomr.org) must be included. 